\title{
MEASURING BANK EFFICIENCY: DEA APPLICATION
}

\author{
Jelena TITKO ${ }^{\mathrm{a}}$, Jelena STANKEVIČIENË ${ }^{\mathrm{b}}$, Nataljja LĀCE ${ }^{c}$ \\ ${ }^{a, c}$ Department of Corporate Finance and Economics, Faculty of Engineering Economics and Management, \\ Riga Technical University, Kalnciema 6, LV-1048 Riga, Latvia \\ ${ }^{\mathrm{b}}$ Department of Finance Engineering, Faculty of Business Management, \\ Vilnius Gediminas Technical University, Sauletekio al. 11, LT-10223 Vilnius, Lithuania
}

Received 09 June 2014; accepted 25 October 2014

\begin{abstract}
The paper aims to improve the methodology of measuring efficiency of Latvian banks. Efficiency scores were calculated with application of non-parametric frontier technique Data Envelopment Analysis (DEA). Input-oriented DEA model under Variable Returns to Scale (VRS) assumption was used. Potential model variables were selected based on the intermediation and profitability approach. Fourteen alternative models with different inputs-outputs combinations were developed for the research purposes. To substantiate the variables selection for DEA model the received data was processed, using such methods, as correlation analysis, linear regression analysis, analysis of mean values, and two-samples Kolmogorov-Smirnov test. The research results assisted the authors in providing general recommendations about the variables selection for DEA application in the Latvian banking sector. The present research contributes to the existing analytical data on bank performance in Latvia. The empirical findings provide a background for further studies, in particular, the efficiency of Latvian banks could be analysed in the extended time period.
\end{abstract}

Keywords: bank efficiency, Latvia, DEA data envelopment analysis.

JEL Classification: C14, C67, G21.

\section{Introduction}

Modern banking business has radically changed over the last decade. The most often mentioned reasons of substantial changes in the banking industry are: 1) globalisation led to decline of barriers to entry in the banking industry; 2) development of the information technologies; 3 ) tightening of the legislation rules; 4) changes in the consumer needs and preferences (Vaithilingam et al. 2006; Greuning, Bratanovic 2009). As the result banks face an increasing competitive pressure from the foreign financial institutions and non-banking

Corresponding author Jelena Stankevičienè

E-mail: jelena.stankeviciene@vgtu.lt 
financial services providers. To survive in the competitive struggle and to achieve the overwhelming goal of shareholder wealth maximization, banks are forced to extend the range of traditional banking functions. Nowadays, banks are not only intermediaries and liquidity providers, but they also act as information channels, risk managers, drivers of innovations, etc. Due to the critically important role of financial institutions in the national economy bank performance is a frequently discussed topic in an academic environment.

In turn, performance of banks is a wide concept concerning such issues, as competition, concentration, efficiency, productivity, and profitability (Bikker, Bos 2008; Heffernan 2005). The wide range of performance-related themes yielded a great diversity on the banking research agenda.

However, there is no consensus among researchers regarding the most appropriate method to measure bank efficiency. Traditional single ratios, such as return on equity, do not provide reliable results due to the complex operational environment of banks (Yang 2009). Applying ratio analysis, it is possible to examine "only a part of the organization's activities" (Arshinova 2011). Efficiency measuring techniques based on the frontier approach allow to overcome this problem by incorporation of multiple inputs and outputs.

The current paper highlights the issue of measuring efficiency performance of banks with a non-parametric frontier technique - data envelopment analysis (DEA). DEA is a widely applied technique for measuring relative efficiency of banks within the sector, making cross-country benchmarking or comparing performance of bank's branches.

A wide range of studies are devoted to the issues of DEA model misspecification (Simar, Wilson 2000; Pastor et al. 2002; Jenkins, Anderson 2003; Fanchon 2003; Ruggiero 2005; Adler, Yazhemsky 2010; Luo, Liang 2012; Xie et al. 2014). The most disputable topic is the choice of inputs and outputs, because the improper variables selection can substantially distort the results' reliability.

The analysis of literature on DEA application yielded a particularly large range of ways the model could be applied (Baležentis et al. 2013; Hajiagha et al. 2013a, 2013b, 2013c; Jaržemskienè 2012; Lee et al. 2012; Nazarko, Šaparauskas 2014; Wong et al. 2012; Zheng et al. 2011). The application of the model to the other managerial cases promises to reveal further potentials to improve the model. The importance of this issue for Latvian banking sector is obvious, considering the lack of relevant studies performed by the local researchers.

The goal of the paper is to substantiate the variables selection for DEA model applied in the Latvian banking sector, thus, improving the methodology of measuring efficiency of Latvian banks.

Data sample consists of financials as for the year 2012 extracted from the annual reports of 15 Latvian banks currently operating in the market. Considering the traditional nature of Latvian banking business, the authors stated the research hypothesis aimed to find arguments pro using intermediation approach for variables selection, applying DEA method in the Latvian banking sector.

H1: Deposits and loans should be used as the key variables in DEA model to measure an efficiency of Latvian banks. 
To achieve the established goal and to test the research hypothesis the authors calculated relative efficiency of Latvian banks, using DEAFrontier software. Fourteen models with different combinations of variables were used for research purposes. The received data was processed with the application of SPSS software, applying such methods, as correlation analysis, linear regression analysis, analysis of mean values, and Kolmogorov-Smirnov test (KS test) for independent samples.

Due to the limited amount of studies in the field of measuring efficiency in Latvian banking sector, the results of the present research are important for analysts who are interested in applying DEA methods for banks' benchmarking. The empirical findings provide a background for further studies; in particular, the results of testing research hypotheses allow to make a reasonable choice of DEA model specification. It is planned to extend the present study, making an investigation of the dynamics of Latvian banks' efficiency over time.

\section{Literature review}

\subsection{Application of data envelopment analysis in measuring bank efficiency}

Data envelopment analysis is one of the most popular methods applied in the studies on measuring efficiency of companies. The authors made a search for DEA-related papers in Scopus, EBSCO and Science Direct data bases. In the result more than 20000 of papers were found.

The number of papers is rather impressive. It indicates the fact that the issues regarding DEA application at measuring efficiency are still on the agenda and require the further investigation. DEA also is widely applied in studies on efficiency issues in banking (Arshinova 2011; Nigmonov 2010; Yang 2009; Zreika, Elkanj 2011; Pančurová, Lyócsa 2013; Ferreira 2012 and others).

However, there is very limited number of studies on bank efficiency with application frontier techniques in the new member states of the European Union, in particular in the Baltic countries. Only a few papers were found by the authors (Arshinova 2011; Eriña, Eriņš 2013; Adamauskas, Krusinskas 2012; Titko, Jurevičiene 2014). Considering that DEA approach has been used since the early 1980's, the methodological and informational gap in studies on bank efficiency conducted by local researchers becomes apparent.

Efficiency of Latvian banks was also measured in the framework of pan-European studies (Ferreira 2012; Anayiotos et al. 2010; Pančurová, Lyócsa 2013). Table 1 provides the review of several scientific papers containing the results of DEA efficiency evaluation in the Latvian banking sector.

When measuring the efficiency of Latvian banks, different authors apply different specifications of DEA model. Diversity of the applied models primarily is determined by various input-output combinations. Considering that improper variable choice can substantially bias measuring results, it is important to study the impact of specific variables on the bank efficiency, using data of Latvian banks' sample. 
Table 1. DEA application for Latvian banking sector

\begin{tabular}{|c|c|c|c|}
\hline Source & $\begin{array}{l}\text { Research } \\
\text { period }\end{array}$ & $\begin{array}{l}\text { DEA model specification } \\
\text { (input-output variables) }\end{array}$ & DEA efficiency \\
\hline Arshinova 2011 & $2003-2008$ & $\begin{array}{l}\text { Inputs - interest expense, personnel costs } \\
\text { Ouputs - deposits }\end{array}$ & $\begin{array}{l}\text { 2004: } 0.769 \\
\text { 2006: } 0.838 \\
\text { 2008: } 0.820\end{array}$ \\
\hline $\begin{array}{l}\text { Pančurová, } \\
\text { Lyócsa } 2013\end{array}$ & $2005-2008$ & $\begin{array}{l}\text { Inputs - Total deposits, total costs } \\
\text { Outputs - Loans, earning assets }\end{array}$ & 2005-2008: 0.376 \\
\hline $\begin{array}{l}\text { Eriņa, Eriņš } \\
2013\end{array}$ & $2006-2011$ & $\begin{array}{l}\text { Inputs - Labour, capital } \\
\text { Outputs - Loans, deposits }\end{array}$ & $\begin{array}{l}\text { 2006: } 0.978 \\
\text { 2007: } 0.911 \\
\text { 2008: } 0.865 \\
\text { 2009: } 0.943 \\
\text { 2010: } 0.899 \\
\text { 2011: } 0.926\end{array}$ \\
\hline Ferreira 2012 & $1996-2008$ & $\begin{array}{l}\text { Inputs - Borrowed funds, physical capital, } \\
\text { labour } \\
\text { Outputs - Total loans, total securities, } \\
\text { other earning assets }\end{array}$ & $\begin{array}{l}\text { 2006: } 0.839 \\
\text { 2007: } 0.721 \\
\text { 2008: } 0.729\end{array}$ \\
\hline $\begin{array}{l}\text { Anayiotos et al. } \\
2010\end{array}$ & 2004-2009 & $\begin{array}{l}\text { Inputs - Total capital, interest expense, } \\
\text { operating expense } \\
\text { Outputs - Total loans, pre-tax profit, } \\
\text { securities }\end{array}$ & $\begin{array}{l}\text { 2004: } 0.650 \\
\text { 2007: } 0.700 \\
\text { 2009: } 0.500\end{array}$ \\
\hline
\end{tabular}

\subsection{Productivity, efficiency and data envelopment analysis}

Productivity and efficiency are the two closely related concepts that are used interchangeably most often (Cooper et al. 2007). Productivity is expressed by the outputs-to-inputs ratio (Lovell 1993). However, the efficiency ratios seem to be more comprehensive. Daraio and Simar define it "as a distance between the quantity of input and output, and the quantity of input and output that defines a frontier, the best possible frontier for a firm in its cluster (industry)" (Daraio, Simar 2007).

The main contributors to the implementation of the analytical approach to measuring efficiency were Debreu with his coefficient of resource utilization (Debreu 1951); Koopmans with his definition of an efficient point (Koopmans 1951) and Farrell with his famous work "The Measurement of Productive Efficiency" (Farrell 1957). Farrell introduced the term "efficient production function" and showed how to measure productive efficiency in practice.

In the current paper the efficiency of Latvian banks was measured with an application of Data Envelopment Analysis (DEA). This method was proposed in 1978 (Charnes et al.1978) and in the academic literature it is referred to as CCR model. DEA helps to identify efficient companies and to construct efficient production frontier. DEA models measure the relative efficiency that is the efficiency of each company relative to similar companies in the sample. Thus, applying DEA in evaluating performance of a set of companies, it is possible to form two clusters: companies that comprise an efficient frontier and inefficient companies lying below the frontier.

Applying DEA model, the efficiency score is estimated as the ratio of weighted outputs to weighted inputs (Charnes et al.1978). Weights are selected for each variable of every analysed 
unit in order to maximize its efficiency score. The efficiency rate for each unit of the reference set of $j=1, \ldots, n$ companies is evaluated relative to the other set members (Charnes et al. 1978). The maximal efficiency score is equal to 1 , and the lower values indicate relative inefficiency of the analysed objects (see Eq. 1):

$$
\begin{gathered}
\max _{0}=\frac{\sum_{r=1}^{s} u_{r} y_{r 0}}{\sum_{i=1}^{m} v_{i} x_{i 0}} ; \\
\text { subject to: } \frac{\sum_{r=1}^{s} u_{r} y_{r j}}{\sum_{i=1}^{m} v_{i} x_{i j}} \leq 1 \quad u_{r}, v_{i} \geq 0 ; j=1, \ldots, n .
\end{gathered}
$$

The fractional model can be transformed to a linear programming problem (see Eq. 2). It should be solved $n$ times for each company in the reference set:

$$
\begin{gathered}
\max _{0} \sum_{r=1}^{s} u_{r} y_{r 0} ; \\
\text { subject to: } \quad \sum_{r=1}^{s} u_{r} y_{r j}-\sum_{i=1}^{m} v_{i} x_{i j} \leq 0 ; \\
\sum_{i=1}^{m} v_{i} x_{i 0}=1 \quad u_{r}, v_{i} \geq 0 ; \quad j=1, \ldots, n .
\end{gathered}
$$

Specification of DEA model is determined by: 1 ) the goal of the optimization task (cost minimization or profit maximization), 2) returns-to-scale assumption (constant returns to scale (CRS) or variable returns to scale (VRS)), and 3) specification of a conceptual approach to business that denotes a combination of model inputs and outputs.

Detailed explanations of CCR model modifications and mathematical transformations are provided, for instance, by Erkoc (Erkoc 2012).

In the studies of banking performance, the input-oriented DEA models are the most frequently used in measuring bank efficiency (Arshinova 2011; Nigmonov 2010; Yang 2009; Zreika, Ekanj 2011). The possible reason is that the bank managers have higher control over inputs rather than over outputs (Fethi, Pasiouras 2010). In the current paper input-oriented DEA is applied.

In regard to scale assumption there is no consensus between researchers. Original DEA model (CCR model) was developed under CRS assumption (Charnes et al.1978), by which is meant that " $t$ times increase in inputs will result in t times increase in output" (Fethi, Pasiouras 2010). Later, the model was modified into the BCC model (Banker et al. 1984) that employed VRS assumption. VRS assumption implies that "equiproportionate increases in factor inputs yield a greater (or less) than equiproportionate increase in output" (Heffernan 2005). Experts point to the fact that CRS can be applied only for the companies which operate at an optimal scale (Coelli et al. 1998). In turn, in many industries (including banking sector) such factors, as imperfect competition or government regulations, may cause the deviation from an optimal scale (Coelli et al. 1998; Beccalli et al. 2006; Singh et al. 2008). Besides, 
VRS is considered to be more appropriate assumption for measuring efficiency in developed banking sector (McAllister, McMaus 1993; Wheelock, Wilson 1995). In the current research DEA model is applied under VRS assumption.

The most frequently discussed question in DEA-related papers is the determination of model variables, i.e., the combination of inputs and outputs. The selection primarily is based on three basic approaches to banking: intermediation approach, production approach and profitability approach. Emphasizing the intermediary role of banks, loans and securities are treated as outputs, whereas deposits, labour and capital as inputs (Sealey, Lindley 1977). Production approach assumes that banks use capital and labour to produce different kinds of banking products, in particular loans and deposits (Heffernan 2005). Profitability approach is quite similar to the production approach, but the outputs of profitability approach are more profit-oriented, such as interest income and non-interest income (Thagunna, Poudel 2013).

The analysis of DEA-related literature yielded a conclusion that basically deposits are treated as inputs, i. e. intermediation approach is prioritized (Shahooth, Battall 2006; Nigmonov 2010; Singh et al. 2008; Beccalli et al. 2006; Thagunna, Poudel 2013).

Table 2 provides the information on DEA model variables used in the latest studies on measuring bank performance.

Table 2. Combination of inputs and outputs employed in DEA models

\begin{tabular}{|c|c|c|}
\hline Source & Inputs & Outputs \\
\hline Thagunna, Poudel 2013 & $\begin{array}{l}\text { Deposits } \\
\text { Interest expense } \\
\text { Operating non-interest expense }\end{array}$ & $\begin{array}{l}\text { Total loans } \\
\text { Interest income } \\
\text { Operating non-interest income }\end{array}$ \\
\hline Karray, Chichti 2013 & $\begin{array}{l}\text { Labour expenses } \\
\text { Fixed assets } \\
\text { Deposits and other borrowed funds }\end{array}$ & $\begin{array}{l}\text { Loans } \\
\text { Other paying assets } \\
\text { Non-interest income } \\
\end{array}$ \\
\hline Hoque, Rayan 2012 & $\begin{array}{l}\text { Operation income } \\
\text { Operation cost } \\
\text { Total assets } \\
\text { Deposits }\end{array}$ & Operation profit \\
\hline Arshinova 2011 & $\begin{array}{l}\text { Interest expense } \\
\text { Personnel costs } \\
\text { Credit impairments }\end{array}$ & Operational profit \\
\hline Nigmonov 2010 & $\begin{array}{l}\text { Operational expenses } \\
\text { Fixed assets } \\
\text { Total Deposits }\end{array}$ & $\begin{array}{l}\text { Net credits } \\
\text { Total non-interest income } \\
\text { Other non-interest income }\end{array}$ \\
\hline Liu et al. 2009 & $\begin{array}{l}\text { Personnel expenses } \\
\text { Business promotion expenses }\end{array}$ & $\begin{array}{l}\text { Number of transactions } \\
\text { Earnings }\end{array}$ \\
\hline Shahooth, Battall 2006 & $\begin{array}{l}\text { Capital } \\
\text { Capital reserves } \\
\text { Deposits } \\
\end{array}$ & $\begin{array}{l}\text { Investments } \\
\text { Assets }\end{array}$ \\
\hline
\end{tabular}

The choice of a model specification has a significant impact on research results. Statistically rigorous methods should be applied for model variables selection. Besides, the number of the variables is quite important, because "the greater the number of variables a 
DEA model has, the more efficient DMUs will be" (Xie et al. 2014) and, thus, the number of efficient companies increases. The researchers should apply DEA method with caution, considering industry- and country-specific factors.

\section{Research methodology}

\subsection{Research environment}

Transition process to the market-oriented economy in the new member states of the European Union led to the liberalization of the financial systems and increased foreign competition. New market players mainly from Scandinavia, Russia and Ukraine entranced Latvian banking sector during the last two decades. Since 2000 the number of Latvian banks remains rather constant. In the year 2014 seventeen local banks and ten financial service providers from the European Economic Area operate in Latvia (ACBL 2014).

Latvian banking sector is highly concentrated, with the top five banks accounting for more than $60 \%$ of the sector's total assets. The largest Latvian banks in terms of assets are Swedbank (18\%), SEB banka (14\%), ABLV bank (11\%), DNB banka (9\%), Rietumu Banka (8,4\%), and Citadele banka (7\%). Market share of the other banks is below 3\%.

Besides, banking sector in Latvia is strongly dominated by foreign investors. Over 70 percent of total contributed capital of Latvian banking system belongs to foreign financial groups and institutions. Only five banks are owned (total participation is greater than $51 \%$ ) by local companies and privates: ABLV bank, Baltikums Bank, Baltic International Bank, Rietumu banka and Latvijas pasta banka. Main shareholder of Citadele Banka is the Latvian government. Shareholders of the largest Latvian banks - Swedbank and SEB banka - are Swedish Swedbank and Skandinaviska Enskilda Banken, respectively. Seven banks are owned by Russian and Ukrainian investors (FCMC 2014a).

Performance of Latvian banks, expressed by return-to-equity ratio, was negatively affected by the global financial crisis. Banking sector of the Baltic States suffered the most, comparing with the other European countries (ECB 2014).

Since 2008 five banks stopped their operations: Parex banka, Latvijas Krajbanka, Ge Money Bank, UniCredit Bank and Latvijas Hipoteku un zemes banka (Mortgage Bank). In 2008 one of the largest Latvian banks - Parex banka - collapsed and Latvian government was forced to take it over. In 2010 Parex Bank was split into a new Bank (Citadele Bank) and a Resolution Bank (Reverta). Insolvency of Latvijas Krajbanka in 2011 was caused by the collapse of its main stockholder - Lithuanian Snoras bank. Ge Money Bank collapsed in 2013 and its customers' accounts were transferred to Citadele bank. Mortgage Bank continues its operations as the state joint-stock company "Altum", commissioned by the government to provide support to specific groups of entrepreneurs and population.

At the moment, situation within the sector is stable. Since 2012 profitability ratios (ROE and ROA) are positive, cost-to-income ratio demonstrates decreasing trend. Bank concentration is $64,1 \%$ in terms of assets, $77 \%$ in terms of loans and $66,7 \%$ in terms of deposits (FCMC 2014b). 
Participants of Latvian banking market are considered to be very traditional ones. Key funding source for Latvian banks remains customers' deposits (62\% of total banking sector's liabilities as for 2012) that are transformed primarily into customers' loans (58\% of total banking sector's assets as for 2012). Only some banks are actively engaged in portfolio investments and have a substantial share of securities in their total assets (as for 2012: ABLV Bank - 25\%; NORVIK BANKA - 28\%; Latvijas pasta banka - 40\%). In the period from 2005 to 2012 the volume of total investments in securities in the Latvian banking sector did not exceed $10 \%$ of total assets.

Thus, the main income source for Latvian banks is interest income that, in turn, primarily is compiled from interest income on loans to customers - since 2004 the share of interest income on loans to non-monetary financial institutions (non-MFIs) in total interest income has been over $70 \%$ in all the years (FCMC 2014b). It should be mentioned, however, that 2008-2009 financial crisis was followed by the significant decrease in the quality of loans of Latvian banks. Studying the relationship between the volume of loans to non-MFIs and interest income from loans to non-MFIs, it was detected that in the pre-crisis period (2004-2008) these variables perfectly correlated (Pearson's $r=0.806$ ), but in 2009-2012 no significant correlation was revealed ((Pearson's $r=0.27)$. In regard to the variable selection process it means that, choosing the items to be treated as outputs in DEA model, external analysts should pay attention to the share of nonperforming loans in banks' balance sheet. Banks with a big share of bad loans could be overestimated, applying DEA model with output represented by volume of loans. In this case the better choice for output is the sum of interest income, net interest income or interest margin.

\subsection{Research design}

Research sample consists of 15 commercial banks operating at the moment in the Latvian banking sector. Branches of foreign financial institutions were not included in the sample, as well as two banks from the list - Bank M2M Europe and Rigensis Bank. The latters were excluded due to the specifics of their business - they do not issue loans to non-MFIs. Data used for the analysis was extracted from the financial statements as for 2012.

The process of the development of DEA model starts with the selection of potential model variables. The most significant items from banks' balance sheet and income statement were selected initially. Besides, net interest margin was added to the list of outputs. Net interest margin is "a proxy for the income generation capacity of the intermediation function of banks" (ECB 2010). Considering that Latvian banks are engaged primarily in traditional banking activities, this measure can adequately reflect the specifics of Latvian banking business.

In the current research the authors did not consider the problem that some variables can be treated as inputs and outputs simultaneously. The restrictions to the status of variables are made: the place of the variables in the list of inputs or outputs is determined a priori (see Table 3). 
Table 3. List of potential model variables

\begin{tabular}{llll}
\hline \multicolumn{1}{c}{ Inputs } & \multicolumn{1}{c}{ Outputs } \\
\hline Input 1 & Deposits from customers & Output 1 & Loans \\
Input 2 & Balances due to credit institutions & Output 2 & Securities \\
Input 3 & Equity & Output 3 & Interest income \\
Input 4 & Interest expense & Output 4 & Commission income \\
Input 5 & Commission expense & Output 5 & Operating profit \\
Input 6 & Staff expense & Output 6 & Net interest margin \\
Input 7 & Total administrative expense & & \\
\hline
\end{tabular}

The next step is to find the appropriate variables to be included in DEA model as inputs and outputs. Many researchers discuss this issue and various methods for selection of variables were proposed (Jenkins, Anderson 2003; Fanchon 2003; Ruggiero 2005; Adler, Yazhemsky 2010; Luo, Liang 2012; Xie et al. 2014). The simplified method to determine relevant variables is to omit highly correlated ones from the list (Jenkins, Anderson 2003; Luo, Liang 2012).

Correlation analysis in SPSS was performed both for the set of inputs and the set of outputs to reveal highly correlated variables within the sample data. Figure 1 and Figure 2 demonstrate the received results.

\begin{tabular}{|c|c|c|c|c|c|c|c|c|}
\hline & & \begin{tabular}{|l}
$\begin{array}{l}\text { Deposits } \\
\text { from } \\
\text { customers }\end{array}$ \\
\end{tabular} & $\begin{array}{l}\text { Balances due } \\
\text { to credit } \\
\text { institutions }\end{array}$ & Equity & $\begin{array}{l}\text { Interest } \\
\text { expense }\end{array}$ & $\begin{array}{c}\text { Commission } \\
\text { expense }\end{array}$ & $\begin{array}{l}\text { Personnel } \\
\text { expense }\end{array}$ & $\begin{array}{c}\text { Administrative } \\
\text { expense }\end{array}$ \\
\hline Deposits from customers & $\begin{array}{l}\text { Pearson Correlation } \\
\text { Sig. (2-tailed) } \\
\mathrm{N}\end{array}$ & $\begin{array}{c}1 \\
15\end{array}$ & $\begin{array}{r}.399 \\
.141 \\
15\end{array}$ & $\begin{array}{l}.789^{* *} \\
.000 \\
15\end{array}$ & $\begin{array}{l}.853^{* \star} \\
.000 \\
15\end{array}$ & $\begin{array}{l}.852^{\star *} \\
.000 \\
15\end{array}$ & $\begin{array}{l}.935^{\star \star} \\
.000 \\
15\end{array}$ & $\begin{array}{l}.910^{* *} \\
.000 \\
15\end{array}$ \\
\hline $\begin{array}{l}\text { Balances due to credit } \\
\text { institutions }\end{array}$ & $\begin{array}{l}\text { Pearson Correlation } \\
\text { Sig. (2-tailed) } \\
\mathrm{N}\end{array}$ & $\begin{array}{r}.399 \\
.141 \\
15 \\
\end{array}$ & $\begin{array}{r}1 \\
15 \\
\end{array}$ & $\begin{array}{c}.632^{*} \\
.011 \\
15 \\
\end{array}$ & $\begin{array}{c}.695^{\star *} \\
.004 \\
15 \\
\end{array}$ & \begin{tabular}{r|}
$.640^{\star}$ \\
.010 \\
15 \\
\end{tabular} & $\begin{array}{c}.558^{*} \\
.031 \\
15 \\
\end{array}$ & \begin{tabular}{c|}
$.618^{\star}$ \\
.014 \\
15 \\
\end{tabular} \\
\hline Equity & $\begin{array}{l}\text { Pearson Correlation } \\
\text { Sig. (2-tailed) } \\
\mathrm{N} \\
\end{array}$ & $\begin{array}{l}.789^{* *} \\
.000 \\
15 \\
\end{array}$ & $\begin{array}{c}.632^{*} \\
.011 \\
15 \\
\end{array}$ & $\begin{array}{r}1 \\
15 \\
\end{array}$ & $\begin{array}{c}.893^{\star \star} \\
.000 \\
15 \\
\end{array}$ & $\begin{array}{c}.937^{* *} \\
.000 \\
15 \\
\end{array}$ & $\begin{array}{l}.831^{* *} \\
.000 \\
15 \\
\end{array}$ & $\begin{array}{l}.887^{* *} \\
.000 \\
15 \\
\end{array}$ \\
\hline Interest expense & $\begin{array}{l}\text { Pearson Correlation } \\
\text { Sig. (2-tailed) } \\
\mathrm{N}\end{array}$ & $\begin{array}{l}.853^{* *} \\
.000 \\
15\end{array}$ & $\begin{array}{l}.695^{* *} \\
.004 \\
15\end{array}$ & $\begin{array}{c}.893^{\star *} \\
.000 \\
15\end{array}$ & $\begin{array}{r}1 \\
15 \\
\end{array}$ & $\begin{array}{c}.942^{\star *} \\
.000 \\
15\end{array}$ & $\begin{array}{l}.945^{* *} \\
.000 \\
15\end{array}$ & $\begin{array}{l}.961^{\star *} \\
.000 \\
15\end{array}$ \\
\hline Commission expense & $\begin{array}{l}\text { Pearson Correlation } \\
\text { Sig. (2-tailed) } \\
\mathrm{N} \\
\end{array}$ & $\begin{array}{l}.852^{* *} \\
.000 \\
15 \\
\end{array}$ & $\begin{array}{c}.640^{*} \\
.010 \\
15 \\
\end{array}$ & $\begin{array}{c}.937^{\star *} \\
.000 \\
15 \\
\end{array}$ & $\begin{array}{c}.942^{* \star} \\
.000 \\
15 \\
\end{array}$ & 15 & $\begin{array}{l}.914^{* *} \\
.000 \\
15 \\
\end{array}$ & $\begin{array}{l}.954^{\star *} \\
.000 \\
15 \\
\end{array}$ \\
\hline Personnel expense & $\begin{array}{l}\text { Pearson Correlation } \\
\text { Sig. (2-tailed) } \\
\text { N }\end{array}$ & $\begin{array}{l}.935^{* *} \\
.000 \\
15\end{array}$ & $\begin{array}{c}.558^{*} \\
.031 \\
15\end{array}$ & $\begin{array}{c}.831^{* *} \\
.000 \\
15\end{array}$ & 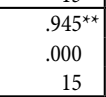 & $\begin{array}{c}.914^{\star \star} \\
.000 \\
15 \\
\end{array}$ & 15 & $\begin{array}{c}.972^{\star \star} \\
.000 \\
15\end{array}$ \\
\hline Administrative expense & $\begin{array}{l}\text { Pearson Correlation } \\
\text { Sig. (2-tailed) } \\
\text { N }\end{array}$ & $\begin{array}{l}.910^{* *} \\
.000 \\
15\end{array}$ & $\begin{array}{l}.618^{*} \\
.014 \\
15\end{array}$ & $\begin{array}{l}.887^{* *} \\
.000 \\
15\end{array}$ & $\begin{array}{l}.961^{\star *} \\
.000 \\
15\end{array}$ & $\begin{array}{l}.954^{* *} \\
.000 \\
15\end{array}$ & $\begin{array}{l}.972^{* *} \\
.000 \\
15\end{array}$ & 15 \\
\hline
\end{tabular}

Fig. 1. Results of the correlation analysis for input variables

Correlation analysis revealed the fact that there is a strong correlation between most of the variables ( ${ }^{* *}$ correlation is significant at 0.01 level). Only two inputs are not highly correlated - deposits from customers and balances due to credit institutions. It means, in turn, that when selecting the inputs for the model we can use either each of the variables 


\begin{tabular}{|c|c|c|c|c|c|c|c|}
\hline & & $\begin{array}{l}\text { Interest } \\
\text { income }\end{array}$ & $\begin{array}{l}\text { Commission } \\
\text { income }\end{array}$ & $\begin{array}{c}\text { Operating } \\
\text { profit }\end{array}$ & $\begin{array}{l}\text { Loans to } \\
\text { customers }\end{array}$ & Securities & $\begin{array}{l}\text { Net interest } \\
\text { margin }\end{array}$ \\
\hline \multirow[t]{3}{*}{ Interest income } & Pearson Correlation & 1 & $.930^{* *}$ & $.969^{* *}$ & $.969^{* *}$ & .305 & .308 \\
\hline & Sig. (2-tailed) & & .000 & .000 & .000 & .270 & .263 \\
\hline & $\mathrm{N}$ & 15 & 15 & 15 & 15 & 15 & 15 \\
\hline \multirow[t]{3}{*}{ Commission income } & Pearson Correlation & $.930^{* *}$ & 1 & $.975^{* *}$ & .865 & .475 & .203 \\
\hline & Sig. (2-tailed) & .000 & & .000 & .000 & .073 & .468 \\
\hline & $\mathrm{N}$ & 15 & 15 & 15 & 15 & 15 & 15 \\
\hline \multirow[t]{3}{*}{ Operating profit } & Pearson Correlation & $.969^{* *}$ & $.975^{* *}$ & 1 & $.914^{* *}$ & .355 & .265 \\
\hline & Sig. (2-tailed) & .000 & .000 & & .000 & .194 & .340 \\
\hline & $\mathrm{N}$ & 15 & 15 & 15 & 15 & 15 & 15 \\
\hline \multirow[t]{3}{*}{ Loans to customers } & Pearson Correlation & $.969^{* \star}$ & $.865^{* \star}$ & $.914^{\star \star}$ & 1 & .171 & .278 \\
\hline & Sig. (2-tailed) & .000 & .000 & .000 & & .543 & .316 \\
\hline & $\mathrm{N}$ & 15 & 15 & 15 & 15 & 15 & 15 \\
\hline \multirow[t]{3}{*}{ Securities } & Pearson Correlation & .305 & .475 & .355 & .171 & 1 & -.125 \\
\hline & Sig. (2-tailed) & .270 & .073 & .194 & .543 & & .658 \\
\hline & $\mathrm{N}$ & 15 & 15 & 15 & 15 & 15 & 15 \\
\hline \multirow[t]{3}{*}{ Net interest margin } & Pearson Correlation & .308 & .203 & .265 & .278 & -.125 & 1 \\
\hline & Sig. (2-tailed) & .263 & .468 & .340 & .316 & .658 & \\
\hline & $\mathrm{N}$ & 15 & 15 & 15 & 15 & 15 & 15 \\
\hline
\end{tabular}

Fig. 2. Results of the correlation analysis for output variables

separately or combine not correlated ones. Taking into account the results of the correlation analysis and considering significance (contribution to the aggregated financial result) of each variable, we selected three alternatives for DEA model input combinations: 1) deposits from customers, 2) deposits from customers and balances due to credit institutions, and 3) interest expense.

The number of uncorrelated output variables is larger, comparing with the set of inputs. All the variables can be used as a singular output in the model. All possible combinations of variables were considered, leading to 63 different combinations of outputs. To reduce this amount, the authors performed regression analysis to define the final set of DEA models to be applied for measuring bank efficiency. Selected inputs (deposits from customers, balances due to credit institutions (further in the text balances due to banks) and interest expense) were treated as predictors, while each of the potential outputs was treated as a dependent variable. The solution is based on the significance of the regression coefficients. Inputs with the statistically significant coefficients could be used with the certain output in one model. Table 4 demonstrates the results of the regression analysis.

Predictors with the statistically significant coefficient ( $\mathrm{p}$-value $<0.05$ ) can be used as explanatory variables for outputs. For instance, interest expense can be treated as input and interest income as output in one model. If a potential output has no variables with statistically significant coefficients (as net interest margin), it can be combined with other uncorrelated outputs.

Based on the results of the correlation analysis (Fig. 1 and Fig. 2) and the regression analysis (Table 4), the authors developed 14 DEA models to calculate efficiency scores. Obviously, the list is quite bigger, but a number of restrictions were stated.

Considering that the total number of the analysed companies should be three times larger than the sum of variables (Jenkins, Anderson 2003; Ruggiero 2005), in our case it is possible 
Table 4. Results of the regression analysis: models with different dependent variables

\begin{tabular}{|c|c|c|c|c|}
\hline \multirow{2}{*}{$\begin{array}{l}\text { Regression model with } \\
\text { the dependent variable }\end{array}$} & \multirow{2}{*}{$\begin{array}{l}\mathrm{R} \text { Square } \\
\text { adjusted }\end{array}$} & \multirow{2}{*}{ Sig. } & \multicolumn{2}{|c|}{ Statistics on coefficients } \\
\hline & & & Predictors & Sig. \\
\hline \multirow{3}{*}{ Loans } & \multirow{3}{*}{0.944} & \multirow{3}{*}{0.000} & Deposits from customers & 0.647 \\
\hline & & & Balances due to banks & 0.013 \\
\hline & & & Interest expense & 0.026 \\
\hline \multirow{3}{*}{ Securities } & \multirow{3}{*}{0.567} & \multirow{3}{*}{0.004} & Deposits from customers & 0.021 \\
\hline & & & Balances due to banks & 0.766 \\
\hline & & & Interest expense & 0.319 \\
\hline \multirow{3}{*}{ Operating profit } & \multirow{3}{*}{0.959} & \multirow{3}{*}{0.000} & Deposits from customers & 0.026 \\
\hline & & & Balances due to banks & 0.614 \\
\hline & & & Interest expense & 0.015 \\
\hline \multirow{3}{*}{ Net interest margin } & \multirow{3}{*}{0.422} & \multirow{3}{*}{0.022} & Deposits from customers & 0.984 \\
\hline & & & Balances due to banks & 0.638 \\
\hline & & & Interest expense & 0.312 \\
\hline \multirow{3}{*}{ Interest income } & \multirow{3}{*}{0.981} & \multirow{3}{*}{0.000} & Deposits from customers & 0.177 \\
\hline & & & Balances due to banks & 0.352 \\
\hline & & & Interest expense & 0.000 \\
\hline \multirow{3}{*}{$\begin{array}{l}\text { Commission } \\
\text { income }\end{array}$} & \multirow{3}{*}{0.966} & \multirow{3}{*}{0.000} & Deposits from customers & 0.001 \\
\hline & & & Balances due to banks & 0.669 \\
\hline & & & Interest expense & 0.108 \\
\hline
\end{tabular}

to employ maximum five inputs and outputs in the model. Besides, some variables cannot be used in one model even in the case they are not the correlated ones. For instance, interest income and net interest margin cannot be outputs simultaneously.

To achieve the established research goals, fourteen different combinations of variables were used to develop DEA models for measuring efficiency of Latvian banks. Models differ also in the number of incorporated variables: five models with two variables, five models with three variables, two models with four variables and two models with five variables (see Table 5).

The developed M1-M14 models were applied to measure relative efficiency of Latvian banks. Considering that DEA assumes all the variables to be non-negative numbers, value of net interest margin for PrivatBank was changed to zero (real value is -0.08).

Efficiency was measured, using DEAFrontier software. Received data was processed in SPSS 20.0 environment. Basic measures of descriptive statistics (min, max, median and standard deviation (StDev)) were calculated for each particular model and each individual bank. Kolmogorov-Smirnov test was applied to compare the data samples received from the application of DEA models with different variables combinations and to define the models providing different results. To reveal the variables contributing the most to the efficiency level regression analysis was performed, using DEA score as a dependent variable and models' inputs and outputs as predictors. 
Table 5. DEA models with different input-output combinations (number of variables)

\begin{tabular}{|c|c|c|c|c|c|}
\hline Model & Inputs & Outputs & Model & Inputs & Outputs \\
\hline M1 (2) & Interest expense & Loans & M8 (3) & $\begin{array}{l}\text { Deposits } \\
\text { Balances due } \\
\text { to banks }\end{array}$ & Securities \\
\hline M2 (2) & Interest expense & $\begin{array}{l}\text { Operating } \\
\text { profit }\end{array}$ & M9 (3) & $\begin{array}{l}\text { Deposits } \\
\text { Balances due } \\
\text { to banks }\end{array}$ & Operating profit \\
\hline M3 (2) & Deposits & Securities & M10 (3) & $\begin{array}{l}\text { Interest } \\
\text { expense }\end{array}$ & $\begin{array}{l}\text { Loans } \\
\text { Securities }\end{array}$ \\
\hline M4 (2) & Deposits & $\begin{array}{l}\text { Operating } \\
\text { profit }\end{array}$ & M11 (4) & $\begin{array}{l}\text { Deposits } \\
\text { Balances due } \\
\text { to banks }\end{array}$ & $\begin{array}{l}\text { Loans } \\
\text { Securities }\end{array}$ \\
\hline M5 (2) & Interest expense & $\begin{array}{l}\text { Interest } \\
\text { income }\end{array}$ & M12 (4) & Deposits & $\begin{array}{l}\text { Securities } \\
\text { Commission income } \\
\text { Net interest margin }\end{array}$ \\
\hline M6 (3) & Deposits & $\begin{array}{l}\text { Loans } \\
\text { Securities }\end{array}$ & M13 (5) & $\begin{array}{l}\text { Deposits } \\
\text { Balances due } \\
\text { to banks }\end{array}$ & $\begin{array}{l}\text { Securities } \\
\text { Loans } \\
\text { Net interest margin }\end{array}$ \\
\hline M7 (3) & $\begin{array}{l}\text { Deposits } \\
\text { Balances due to } \\
\text { banks }\end{array}$ & Loans & M14 (5) & $\begin{array}{l}\text { Deposits } \\
\text { Balances due } \\
\text { to banks }\end{array}$ & $\begin{array}{l}\text { Securities } \\
\text { Commission income } \\
\text { Net interest margin }\end{array}$ \\
\hline
\end{tabular}

\section{Research results}

Application of input-oriented DEA models under VRS assumption yielded efficiency scores for the analysed banks (see Table 6 and Table 7).

Table 6. Efficiency scores estimated for Latvian banks, using models M1-M7

\begin{tabular}{lccccccc}
\hline \multicolumn{1}{c}{ Bank name } & M1 & M2 & M3 & M4 & M5 & M6 & M7 \\
\hline ABLV Bank & 0.501 & 0.650 & 1 & 0.401 & 0.760 & 1 & 1 \\
Baltikums Bank & 0.872 & 1 & 0.166 & 0.915 & 1 & 0.193 & 0.243 \\
Baltic International Bank & 0.524 & 0.286 & 0.251 & 0.735 & 0.711 & 0.396 & 0.697 \\
Citadele banka & 0.423 & 0.427 & 0.558 & 0.638 & 0.700 & 0.718 & 0.951 \\
Swedbank & 1 & 1 & 0.157 & 1 & 1 & 1 & 1 \\
NORVIK BANKA & 0.437 & 0.364 & 1 & 0.785 & 0.513 & 1 & 1 \\
SEB banka & 1 & 0.458 & 0.101 & 0.714 & 0.875 & 1 & 1 \\
Meridian Bank (SMP Bank in 2012) & 1 & 0.417 & 0.296 & 0.634 & 0.577 & 0.524 & 1 \\
DNB banka & 0.841 & 0.406 & 0.278 & 1 & 0.771 & 1 & 1 \\
PrivatBank & 0.213 & 0.114 & 0.104 & 0.358 & 0.217 & 0.177 & 0.263 \\
Regionala investiciju banka & 0.163 & 0.091 & 0.157 & 0.573 & 0.454 & 0.264 & 0.478 \\
Rietumu Banka & 0.755 & 1 & 0.065 & 0.720 & 1 & 0.278 & 1 \\
TRASTA KOMERCBANKA & 0.485 & 0.255 & 0.233 & 0.892 & 0.569 & 0.371 & 0.713 \\
Latvijas pasta banka & 0.814 & 0.703 & 1 & 1 & 0.810 & 1 & 1 \\
Expobank & 1 & 1 & 0.267 & 0.502 & 1 & 0.267 & 0.267 \\
\hline
\end{tabular}


Table 7. Efficiency scores estimated for Latvian banks, using models M8-M14

\begin{tabular}{lccccccc}
\hline \multicolumn{1}{c}{ Bank name } & M8 & M9 & M10 & M11 & M12 & M13 & M14 \\
\hline ABLV Bank & 1 & 1 & 1 & 1 & 1 & 1 & 1 \\
Baltikums Bank & 0.166 & 1 & 0.990 & 0.243 & 1 & 0.243 & 1 \\
Baltic International Bank & 0.251 & 1 & 0.553 & 0.702 & 0.535 & 1 & 1 \\
Citadele banka & 0.558 & 0.883 & 0.541 & 1 & 1 & 1 & 1 \\
Swedbank & 0.157 & 1 & 1 & 1 & 1 & 1 & 1 \\
NORVIK BANKA & 1 & 1 & 0.700 & 1 & 1 & 1 & 1 \\
SEB banka & 0.101 & 0.714 & 1 & 1 & 0.827 & 1 & 0.827 \\
Meridian Bank (SMP Bank in 2012) & 0.296 & 1 & 1 & 1 & 0.482 & 1 & 1 \\
DNB banka & 0.278 & 1 & 0.864 & 1 & 0.651 & 1 & 0.651 \\
PrivatBank & 0.104 & 0.385 & 0.213 & 0.263 & 0.321 & 0.263 & 0.321 \\
Regionala investiciju banka & 0.157 & 0.645 & 0.184 & 0.492 & 0.324 & 0.492 & 0.324 \\
Rietumu Banka & 0.065 & 1 & 0.775 & 1 & 0.688 & 1 & 1 \\
TRASTA KOMERCBANKA & 0.233 & 0.971 & 0.588 & 0.752 & 0.700 & 0.752 & 0.700 \\
Latvijas pasta banka & 1 & 1 & 1 & 1 & 1 & 1 & 1 \\
Expobank & 0.267 & 0.547 & 1 & 0.267 & 0.267 & 0.267 & 0.267 \\
\hline
\end{tabular}

Without any statistical analysis, it is obvious that the best results are demonstrated by Swedbank, ABLV Bank, NORVIK BANKA and Latvijas pasta banka, which have $100 \%$ efficiency in 12, 10, 9 and 11 cases respectively. In turn, TRASTA KOMERCBANKA, PrivatBank and Regionala investiciju banka are inefficient whatever model specification is applied.

Table 8 summarizes the descriptive statistics measures for each particular model. Applying all the models, the maximal efficiency score is equal to 1 , meaning that at least one bank in the sample was efficient. However, the distance between minimum and maximum is quite large. For instance, applying M3 and M8 models, the most efficient bank and the least efficient bank have difference in DEA scores equal to 0.935 !

Table 9 summarizes the statistics measures, calculated for each individual bank. The results of almost all banks deviate significantly. Besides, ten banks from the sample demonstrate the lowest efficiency, calculated with the application of M3 and M8 models.

Table 8. Results of the application of M1-M14 models: descriptive statistics

\begin{tabular}{cccccccccc}
\hline Model & Median & Min & Max & StDev & Model & Median & Min & Max & StDev \\
\hline M1 & 0.755 & 0.163 & 1.000 & 0.283 & M8 & 0.251 & 0.065 & 1.000 & 0.332 \\
M2 & 0.427 & 0.091 & 1.000 & 0.316 & M9 & 1.000 & 0.385 & 1.000 & 0.196 \\
M3 & 0.251 & 0.065 & 1.000 & 0.332 & M10 & 0.864 & 0.184 & 1.000 & 0.279 \\
M4 & 0.720 & 0.358 & 1.000 & 0.204 & M11 & 1.000 & 0.243 & 1.000 & 0.299 \\
M5 & 0.760 & 0.217 & 1.000 & 0.225 & M12 & 0.700 & 0.267 & 1.000 & 0.271 \\
M6 & 0.524 & 0.177 & 1.000 & 0.341 & M13 & 1.000 & 0.243 & 1.000 & 0.303 \\
M7 & 1.000 & 0.243 & 1.000 & 0.299 & M14 & 1.000 & 0.267 & 1.000 & 0.275 \\
\hline
\end{tabular}


Table 9. Efficiency of Latvian banks calculated with M1-M14 models: descriptive statistics

\begin{tabular}{lcccc}
\hline \multicolumn{1}{c}{ Bank name } & Median & Min & Max & StDev \\
\hline ABLV Bank & 1.000 & 0.401 & 1.000 & 0.204 \\
Baltikums Bank & 0.893 & 0.166 & 1.000 & 0.380 \\
Baltic International Bank & 0.625 & 0.251 & 1.000 & 0.257 \\
Citadele banka & 0.709 & 0.423 & 1.000 & 0.216 \\
Swedbank & 1.000 & 0.157 & 1.000 & 0.295 \\
NORVIK BANKA & 1.000 & 0.364 & 1.000 & 0.231 \\
SEB banka & 0.851 & 0.101 & 1.000 & 0.309 \\
Meridian Bank (SMP Bank in 2012) & 0.817 & 0.296 & 1.000 & 0.283 \\
DNB banka & 0.852 & 0.278 & 1.000 & 0.264 \\
PrivatBank & 0.240 & 0.104 & 0.385 & 0.088 \\
Regionala investiciju banka & 0.324 & 0.091 & 0.645 & 0.172 \\
Rietumu Banka & 0.887 & 0.065 & 1.000 & 0.338 \\
TRASTA KOMERCBANKA & 0.644 & 0.233 & 0.971 & 0.232 \\
Latvijas pasta banka & 1.000 & 0.703 & 1.000 & 0.095 \\
Expobank & 0.267 & 0.267 & 1.000 & 0.320 \\
\hline
\end{tabular}

To reveal the models providing significantly different results, Kolmogorov-Smirnov test was applied. Data received with the application of two different models was compared, applying KS test for 91 pair of the developed 14 models (see Table 5). Table 10 demonstrates only the cases when the null hypothesis (samples are drawn from the same distribution) was rejected and the Kolmogorov-Smirnov statistic was significant at 0.05 level.

Analysing the result of KS test, it was revealed that the models M3 and M8 provide significantly different results, comparing with all other models. The reason is that only these particular models have Securities as a single output (see Table 5). Considering that the most Latvian banks are not actively engaged in securities investment business, it is clear why their efficiency decreases dramatically, applying these models. In turn, ABLV Bank, NORVIK BANKA and Latvijas pasta banka, which have substantial share of securities in their assets, demonstrate $100 \%$ efficiency with application of M3 and M8. However, we need the model with no discriminating effect. That is why the analysts should avoid using DEA models with Securities treated as a single output. However, Securities can be used as output in combination with another variable, for instance, Loans.

To specify the most appropriate variables for inclusion into DEA model, KS test results were used to reveal the cases when the null hypothesis (samples are drawn from the same distribution) was confirmed. Ten pairs of models were found and common variables were detected (see Table 11).

In seven cases the common variable is Deposits from customers. To test the assumption that deposits determine data similarity, regression analysis was performed. DEA efficiency calculated with the models M4, M7, M11, M12, M13, and M14 was used as a dependent variable, inputs and outputs of the corresponding model were used as predictors. The authors tested two alternatives for each model: with and without Deposits. In some cases adjusted $\mathrm{R}^{2}$ 
Table 10. The results of Kolmogorov-Smirnov two-sample test

\begin{tabular}{cccccc}
\hline Pair of models & Sig. & Pair of models & Sig. & Pair of models & Sig. \\
\hline M1 M3 & 0.008 & M3 M10 & 0.008 & M7 M8 & 0.023 \\
M1 M8 & 0.008 & M3 M11 & 0.023 & M8 M9 & 0.000 \\
M2 M9 & 0.020 & M3 M12 & 0.002 & M8 M10 & 0.008 \\
M3 M4 & 0.000 & M3 M13 & 0.020 & M8 M11 & 0.023 \\
M3 M5 & 0.002 & M3 M14 & 0.002 & M8 M12 & 0.002 \\
M3 M7 & 0.023 & M4 M8 & 0.000 & M8 M13 & 0.020 \\
M3 M9 & 0.000 & M5 M8 & 0.002 & M8 M14 & 0.002 \\
\hline
\end{tabular}

Table 11. The results of Kolmogorov-Smirnov two-sample test

\begin{tabular}{|c|c|c|c|c|c|}
\hline Models & Sig. & Common variables & Models & Sig. & Common variables \\
\hline M4 M5 & 0.999 & No variables & M7 M13 & 0.980 & $\begin{array}{l}\text { Deposits; Balances due to banks; } \\
\text { Loans }\end{array}$ \\
\hline M4 M12 & 0.904 & Deposits & M7 M14 & 0.980 & Deposits; Balances due to banks \\
\hline M5 M12 & 0.998 & No variables & M11 M13 & 1.000 & $\begin{array}{l}\text { Deposits; Balances due to banks; } \\
\text { Loans; Securities }\end{array}$ \\
\hline M7 M10 & 0.994 & Loans & M11 M14 & 0.980 & Deposits; Balances due to banks \\
\hline M7 M11 & 1.000 & $\begin{array}{l}\text { Deposits; Balances } \\
\text { due to banks; Loans }\end{array}$ & M13 M14 & 0.962 & $\begin{array}{l}\text { Deposits; Balances due to banks; } \\
\text { Securities; NIM }\end{array}$ \\
\hline
\end{tabular}

even increased, removing Deposits from the model. Thus, we have no statistically significant evidence that Deposits have the significant impact on DEA score.

The same analysis was performed in regard to Loans. Variables of the M7, M10, M11, and M13 were used for regression analysis, using as a dependent variable DEA scores calculated with the corresponding model. Based on the results, Loans also cannot be considered as the significant contributor to the efficiency measure.

The results point to the fact that we cannot confirm the research hypothesis. This issue requires the further investigation with the larger data sample.

As the last step of the research 14 regression equations were constructed, using DEA scores as a dependent variable and all the model variables as predictors. The models were ranked from the highest value of the adjusted $\mathrm{R}^{2}$ to the lowest. M13, M12, and M14 models were on the top with the adjusted $\mathrm{R}^{2}$ equal to $0.923,0.907$ and 0.889 respectively. However, regression coefficients were not statistically significant. Probably, another set of models with different variables combinations should be developed and the results of their application should be tested to get more conclusive data.

\section{Conclusions}

In the current paper efficiency of Latvian banks was measured with application of input-oriented DEA model under VRS assumption. Based on the DEA-related literature review, fourteen alternative model specifications were developed, considering the results of previously 
conducted correlation analysis. Highly correlated variables were not included in one model. Besides, regression analysis was used to substantiate variables selection.

The best results were demonstrated by Swedbank, ABLV Bank, NORVIK BANKA and Latvijas pasta banka. In turn, TRASTA KOMERCBANKA, PrivatBank and Regionala investiciju banka are inefficient whatever model specification was applied. Top five Latvian banks in terms of assets also make top five in terms of efficiency. Swedbank (1.000) ABLV Bank (1.000) are the leaders. Rietumu banka (0.887), DNB banka (0.852) and SEB banka (0.851) take the third, fourth and fifth place respectively. The worst results (lowest average efficiency) are demonstrated by Regionala investiciju banka (0.324), Expobank (0.267) and PrivatBank (0.240).

Research hypothesis stated by the authors -Deposits and loans should be used as the key variables in DEA model to measure efficiency of Latvian banks - was rejected.

The authors did not find any statistical evidence to support the hypothesis. The attempt to reveal the variable with the large contribution to the efficiency scores failed. The issue of variables selection to apply DEA method in the Latvian banking sector requires further investigation.

At the current moment the authors can provide only general recommendations. For instance, Securities cannot be used as a single output in DEA model for measuring efficiency of Latvian banks. The reason is that only several banks in the market deal with securities investments rather actively. It is better to use variables reflecting business specifics of all the market players to get fair results. Besides, during the period of financial turbulence it is better to use Interest income or other profit-oriented variables (net interest income, net interest margin or operating profit) as outputs instead of Loans due to the large share of non-performing loans in banks' assets.

For the future research the larger set of potential variables could be used. Besides, the developed models could be applied using latest financial data.

\section{Acknowledgements}

Support for this work was provided by the Riga Technical University through the Scientific Research Project Competition for Young Researchers No. ZP-2013/03.

\section{References}

Adamauskas, S.; Krusinskas, R. 2012. Behavioural finance efficiency under the influence of country's economic cycle, Inzinerine ekonomika - Engineering Economics 23(4): 327-337.

Adler, N.; Yazhemsky, E. 2010. Improving discrimination in data envelopment analysis: PCA-DEA or variable reduction, European Journal of Operational Research 202(1): 273-284. http://dx.doi.org/10.1016/j.ejor.2009.03.050

Anayiotos, G.; Toroyan, H.; Vamvakidis, A. 2010. The efficiency of emerging Europe's banking sector before and after the recent economic crisis, Financial Theory and Practice 34(3): 247-267.

Arshinova, T. 2011. The banking efficiency measurement using the frontier analysis techniques, Journal of Applied Mathematics 4(3): 165-176.

Association of Commercial Banks of Latvia (ACBL). 2014. The Banking Sector in Figures [online], [cited 10 March 2014]. The Association of Commercial Banks of Latvia. Available from Internet: http://www.bankasoc.lv/en/statistics/ 
Baležentis, T.; Misiūnas, A.; Baležentis, A. 2013. Efficiency and productivity change across the economic sectors in Lithuania (2000-2010): the DEA-MULTIMOORA approach, Technological and Economic Development of Economy 19(Supplement 1): S191-S213. http://dx.doi.org/10.3846/20294913.2013.881431

Banker, R.; Charnes, A.; Cooper, W. W. 1984. Some models for estimating technical and scale inefficiencies in data envelopment analysis, Management Science 30: 1078-1092. http://dx.doi.org/10.1287/mnsc.30.9.1078

Beccalli, E.; Casu, B.; Girardone, C. 2006. Efficiency and stock performance in European banking, Journal of Business Finance \& Accounting 33(1-2): 245-262. http://dx.doi.org/10.1111/j.1468-5957.2006.01362.x

Bikker, J. A.; Bos, J. W. B. 2008. Bank performance: a theoretical and empirical framework for the analysis of profitability, competition and efficiency. New York: Routledge.

Charnes, A.; Cooper, W. W.; Rhodes, E. 1978. Measuring the efficiency of decision-making units, European Journal of Operational Research 2: 429-444. http://dx.doi.org/10.1016/0377-2217(78)90138-8

Coelli, T.; Rao, D. S.; Battese, G. E. 1998.An introduction to efficiency and productivity analysis. NY: Springer. http://dx.doi.org/10.1007/978-1-4615-5493-6

Cooper, W. W.; Seiford, L. M.; Tone, K. 2007. Data envelopment analysis: a comprehensive text with models, applications, references and DEA-solver software. New York: Springer.

Daraio, C.; Simar, L. 2007. Advanced robust and nonparametric methods in efficiency analysis: methodology and applications. New York: Springer.

Debreu, G. 1951. The coefficient of resource utilization, Econometrica 19(3): 273-292. http://dx.doi.org/10.2307/1906814

Eriņa, J.; Eriņš, I. 2013. Efficiency of the Latvian commercial banking system: a DEA model evaluation, in 18th International Scientific Conference "Economics and Management - 2013", 24-26 April 2013, Kaunas, Lithuania.

Erkoc, T. E. 2012. Estimation methodology of economic efficiency: stochastic frontier analysis vs. data envelopment analysis, International Journal of Academic Research in Economics and Management Sciences 1(1): 1-23.

European Central Bank (ECB). 2010. Beyond ROE - how to measure bank performance? [online], [cited 11 October 2014]. European Central Bank. Available from Internet: http://www.ecb.europa.eu/pub/ pdf/other/beyondroehowtomeasurebankperformance201009en.pdf

European Central Bank (ECB). 2014. Consolidated Banking Data 2004-2012 [online], [cited 1 March 2014]. European Central Bank. Available from Internet: http://sdw.ecb.europa.eu/browse.do? node=71390

Fanchon, P. 2003. Variable selection for dynamic measures of efficiency in the computer industry, International Advances in Economic Research 9(3): 175-188. http://dx.doi.org/10.1007/BF02295441

Farrell, M. J. 1957. The measurement of productive efficiency, Journal of Royal Statistical Society 120(A): 253-281.

Ferreira, C. 2012. Bank efficiency, market concentration and economic growth in the European Union. WP 08/2011/DE/UECE. Technical University of Lisbon, Lisbon.

Fethi, M. D.; Pasiouras, F. 2010. Assessing bank efficiency and performance with operational research and artificial intelligence techniques: a survey, European Journal of Operational Research 204(2): 189-198. http://dx.doi.org/10.1016/j.ejor.2009.08.003

Financial and Capital Market Commission (FCMC). 2014a. Banks [online], [cited 10 March 2014]. Available from Internet: http://fktk.lv/en/market/credit_institutions/banks1/

Financial and Capital Market Commission (FCMC). 2014b. Quarterly Reports 2004-2014 [online], [cited 10 March 2014]. Available from Internet: http://fktk.lv/en/statistics/credit_institutions/quarterly_reports/

Greuning, H.; Bratanovic, S. B. 2009. Analyzing banking risk: a framework for assessing corporate governance and risk management. IBRD/World Bank, Washington. 
Hajiagha, S. H. R.; Akrami, H.; Zavadskas, E. K; Hashemi, S. S. 2013a. An intuitionistic fuzzy data envelopment analysis for efficiency evaluation under uncertainty: case of a finance and credit institution, E\&M Ekonomie a Management 16(1): 128-137.

Hajiagha, S. H R.; Zavadskas, E. K; Hashemi, S. S. 2013b. Application of stepwise data envelopment analysis and grey incidence analysis to evaluate the effectiveness of export promotion programs, Journal of Business Economics and Management 14(3): 638-650. http://dx.doi.org/10.3846/16111699.2012.745819

Hajiagha, S. H. R.; Mahdiraji, H. A.; Zavadskas, E. K.; Hashemi, S. S. 2013c. A fuzzy data envelopment analysis approach based on parametric programming, International Journal of Computers Communications \& Control 8(4): 594-607. http://dx.doi.org/10.15837/ijccc.2013.4.580

Heffernan, S. 2005. Modern Banking. Chichester: John Wiley \& Sons, Ltd.

Hoque, R.; Rayan, I. 2012. Data envelopment analysis of banking sector, Expert Systems with Applications 39(9): 8212-8219.

Jaržemskienè, I. 2012. Applying the method of measuring airport productivity in the Baltic region, Transport 27(2): 178-186. http://dx.doi.org/10.3846/16484142.2012.694079

Jenkins, L.; Anderson, M. 2003. A multivariate statistical approach to reducing the number of variables in data envelopment analysis, European Journal of Operational Research 147(1): 51-61.

http://dx.doi.org/10.1016/S0377-2217(02)00243-6

Karray, S. Ch.; Chichti, J. 2013. Bank size and efficiency in developing countries: intermediation approach versus value added approach and impact of non-traditional activities, Asian Economic and Financial Review 3(5): 593-613.

Koopmans, T. C. 1951. An analysis of production as an efficient combination of activities, in T. C. Koopmans (Eds.). Activity analysis of production and allocation. NY: John Wiley and Sons, Inc.

Lee, G.; Yu, M.-M.; Wang, L.-Ch. 2012. DEA-based integrated relationship of returns to scale - an application to road maintenance in Taiwan, Journal of Civil Engineering and Management 18(5): 709-723. http://dx.doi.org/10.3846/13923730.2012.723394

Liu, Z.-J.; Lin, F.; Fang, L.-P. 2009. Study of applying DEA to measure performance on bank implementing financial electronic data interchange, Journal of Electronic Business Management 7(4): 268-277.

Lovell, C. K. 1993. Production frontiers and productive efficiency, Chapter 1 in A. O. Fried, A. K. Lovell, S. S. Schmidt (Eds.). The measurement of productive efficiency. Oxford: University Press.

Luo, Y.; Bi, G.; Liang, L. 2012. Input/output indicator selection for DEA efficiency evaluation: an empirical study of Chinese commercial banks, Expert Systems with Applications 39(1): 1118-1123. http://dx.doi.org/10.1016/j.eswa.2011.07.111

McAllister, P. H.; McMaus, D. 1993.Resolving the scale efficiency puzzle in banking, Journal of Banking and Finance 17: 389-405. http://dx.doi.org/10.1016/0378-4266(93)90039-G

Nazarko, J.; Šaparauskas, J. 2014. Application of DEA method in efficiency evaluation of public higher education institutions, Technological and Economic Development of Economy 20(1): 25-44. http://dx.doi.org/10.3846/20294913.2014.837116

Nigmonov, A. 2010. Bank performance and efficiency in Uzbekistan, Eurasian Journal of Business and Economics 3(5): 1-25.

Pančurová, D.; Lyócsa, S. 2013. Determinants of commercial banks' efficiency: evidence from 11 CEE countries, Czech Journal of Economics and Finance 63(2): 152-179.

Pastor, J. T.; Ruiz, J. L.; Sirvent, I. 2002. A statistical test for nested radial DEA models, Operations Research 50(4): 728-735. http://dx.doi.org/10.1287/opre.50.4.728.2866

Ruggiero, J. 2005. Impact assessment of input omission on DEA, International Journal of Information Technology \& Decision Making 4(03): 359-368. http://dx.doi.org/10.1142/S021962200500160X 
Sealey, C. W.; Lindley, J. T. 1977. Inputs, outputs, and a theory of production and cost at depository financial institutions, The Journal of Finance 32(4): 1251-1266. http://dx.doi.org/10.1111/j.1540-6261.1977.tb03324.x

Shahooth, K.; Battall, A. H. 2006. Using data envelopment analysis to measure cost efficiency with an application on Islamic banks, Scientific Journal of Administrative Development 4: 134-156.

Simar, L.; Wilson, P. W. 2000. A general methodology for bootstrapping in non-parametric frontier models, Journal of Applied Statistics 27(6): 779-802. http://dx.doi.org/10.1080/02664760050081951

Singh, G.; Singh, P.; Munisamy, S. 2008. A cross country comparison of banking efficiency: Asia Pacific banks, International Review of Business Research Papers 4(3): 73-95.

Thagunna, K. S.; Poudel, S. 2013. Measuring bank performance of Nepali banks: a data envelopment analysis (DEA) perspective, International Journal of Economics and Financial Issues 3(1): 54-65.

Titko, J.; Jurevičiene, D. 2014. DEA application at cross-country benchmarking: Latvian vs. Lithuanian banking sector, Procedia - Social and Behavioral Sciences 110: 1124-1135.

Vaithilingam, S.; Nair, M.; Samudram, M. 2006. Key drivers for soundness of the banking sector; lessons for developing countries, Journal of Global Business \& Technology 2(1): 10.

Wheelock, D. C.; Wilson, P. 1995. Why do banks disappear: the determinants of bank failures and acquisitions, The Review of Economics and Statistics 82: 127-138. http://dx.doi.org/10.1162/003465300558560

Wong, W. P.; Gholipour, H. F.; Bazrafshan, E. 2012. How efficient are real estate and construction companies in Iran's close economy?, International Journal of Strategic Property Management 16(4): 392-413. http://dx.doi.org/10.3846/1648715X.2012.740513

Xie, Q.; Dai, Q.; Li, Y.; Jiang, A. 2014. Increasing the discriminatory power of DEA using Shannon's entropy, Entropy 16(3): 1571-1585. http://dx.doi.org/10.3390/e16031571

Yang, Z. 2009. Bank branch operating efficiency: a DEA approach, in The International MultiConference of Engineers and Computer Scientists (IMECS 2009), 18-20 March 2009, Hong Kong.

Zheng, X.; Chau, K.-W.; Hui, E. C. M. 2011. Efficiency assessment of listed real estate companies: an empirical study of China, International Journal of Strategic Property Management 15(2): 91-104. http://dx.doi.org/10.3846/1648715X.2011.582739

Zreika, M.; Elkanj, N. 2011. Banking efficiency in Lebanon: an empirical investigation, Journal of Social Sciences 7(2): 199-208.

Jelena TITKO is an Assistant Professor at the Department of Corporate Finance and Economics of Riga Technical University (Latvia). Areas of her research interest: performance management and customer relationship management in banking, drivers of bank value, service quality and customer satisfaction, valuation of a company, financial literacy.

Jelena STANKEVIČIENĖ is a Professor at the Department of Finance Engineering of Vilnius Gediminas Technical University (Lithuania). Her main research topics include assets and liability management, regulation of financial institution, financial management for value creation, value engineering.

Natalija LĀCE is a Professor at Riga Technical University (Latvia). She is a head of the Department of Corporate Finance and Economics. Areas of her research interest: business financial management, critical success factors of small and medium-sized enterprises, personal finance, corporate finance, company's viability. 